\title{
Modelling Pittwater Lagoon for risk assessment of an effluent spill
}

\author{
$\underline{\text { Karen Wild-Allen }}^{\mathrm{a}}$, John Andrewartha ${ }^{\mathrm{a}}$, Royce Aldred ${ }^{\mathrm{b}}$, Judi Marshall $^{\mathrm{b}, \mathrm{c}}$ \\ ${ }^{a}$ CSIRO Oceans \& Atmosphere, GPO Box 1538, Hobart 7001, TAS. \\ ${ }^{b}$ TasWater, GPO Box 1393, Hobart 7001, TAS. \\ ${ }^{c}$ Phycotec Environmental Management, Clifton Beach 7020, TAS. \\ Email: karen.wild-allen@csiro.au
}

\begin{abstract}
We present a model system that quantifies the spatial and temporal footprint of passive tracer release to inform the assessment of risk of microbial contamination associated with a waste water effluent spill. Whilst biological contaminants are dynamic in nature a passive tracer can be used as a proxy over short timescales to quantify the spatial and temporal footprint of risk. The model system is demonstrated in Pittwater Lagoon, southeast Tasmania and operates in near-real-time with a 1-2 day forecast capability for live prediction of waste water spill dispersal.
\end{abstract}

The CSIRO SHOC hydrodynamic model was implemented on a very fine resolution curvilinear 3D grid (40 $\mathrm{m}$ horizontal; $0.5 \mathrm{~m}$ vertical) and assessed against in situ observations collected by near real time sensors reporting pressure, temperature and salinity. The timing and magnitude of observed fluctuations in temperature, salinity and sea level were well reproduced by the model indicating that the main drivers of the thermal, salinity and flushing dynamics were well captured by the model, and confirming that the model is suitable for the investigation of potential spill dispersal scenarios. Near real time simulation of potential effluent spills was achieved by the periodic release of passive tracer particles from known vulnerable locations in the inner- and outer-Lagoon. Movie loops of particle dispersal from each location are displayed on the web and results are updated every few days to provide a synopsis of recent conditions and a short term forecast. In addition eleven specific hind-cast spill scenario simulations were implemented to explore the impact of variations in river in-flow, Spring-Neaps tidal cycles and wind direction on spill dispersal proximal to oyster leases. Model results were analysed to calculate the time taken for $1 \%$ of the spill source to arrive at each of 31 separate oyster lease locations. In general spills in the inner Lagoon rapidly arrived at oyster leases in the inner Lagoon (in less than 1 day), whilst spills in the outer Lagoon rapidly arrived at leases in the outer Lagoon. During spring tides spills were more rapidly distributed throughout the region and arrived at oyster leases faster than under comparable conditions at neap tides. Wind impacted the trajectory of spills with northwest winds slowing the dispersal of distant sources into the inner Lagoon by several days (compared to northeast winds). Under high river in-flow oyster leases in the inner Lagoon were quickly impacted by potential river effluent, but under low river in-flow this source did not spread to any lease within a week.

These scenario simulations have provided valuable insight into the dynamics of potential effluent spills in Pittwater Lagoon and their impact on local oyster leases. In addition, the ongoing near real time and forecast model provides continuous and timely insight of the potential risk of effluent spills for science based resource management. This study can be generalized and applied to other shellfish farming areas and species.

Keywords: Spill dispersal, risk forecast, hydrodynamic model, coastal lagoon 


\section{INTRODUCTION}

Filter feeding bivalves such as oysters and mussels are vulnerable to microbial contamination by ingestion of contaminated water resulting in human health concerns in consumers (Fleming et al., 2006; Oliveira et al., 2011). Pathogens such as Escherichia coli and Norovirus are of particular concern as they can result in severe gastroenteritis resulting in hospitalization and even death in vulnerable individuals (Butt et al., 2004; Lees 2000). To avoid the consumption of contaminated shellfish, commercial fisheries operate under stringent regulation with routine and frequent testing of water quality and shellfish products.

In southeast Tasmania, Pittwater Lagoon provides an ideal environment for the farming of pacific oysters (Magallana gigas). Coastal urban development is relatively sparse, although the associated storm water drains and any failures in the wastewater infrastructure, have the potential to deliver microbial contamination into the lagoon [and augment the naturally occurring microbial contamination from populations of birds in the adjacent Coal River and Orielton Lagoon (Woehler 2013)]. The opening and closing of oyster leases for harvesting in Pittwater Lagoon is regulated by the, Tasmanian Shellfish Quality Assurance Program (TSQAP) which is part of the State Department of Primary Industries, Parks Wildlife and the Environment (DPIPWE). Leases are closed for harvesting for at least 21 days following likelihood of microbial contamination proximal to the site.

The likelihood of microbial contamination of oyster leases in Pittwater Lagoon is assessed from factors including rainfall, river flow, in situ samples, and any known contamination incident or waste water effluent spill. Whilst it is wise to manage risks to human health conservatively, it is likely that in recent years numerous days of oyster harvesting have been unnecessarily lost due to general application of lease closures throughout the whole Lagoon system, when only part of the area may have been compromised.

The aim of this project was to develop a model system to inform the assessment of risk associated with an effluent spill incident in Pittwater Lagoon. Whilst biological contaminants are non-conservative, for a first order analysis we quantified the spatial and temporal footprint of passive tracer releases over short timescales. The model system was envisaged to operate in near-real-time with a 1-2 day forecast capability for live prediction of first order spill dispersal. Detailed analysis of a number of specific spill scenario simulations was also achieved.

\section{MODEL DESCRIPTION}

The CSIRO SHOC hydrodynamic model (Herzfeld et al., 2010) was implemented for Pittwater Lagoon in southeast Tasmania on a curvilinear grid with horizontal resolution 40 to $300 \mathrm{~m}$ and vertical resolution 0.5 to $2 \mathrm{~m}$ (Figure 1). The model was forced with data from the Australian Bureau of Meteorology's atmospheric model ACCESS, marine boundary conditions from the SETAS model (Jones et al., 2012; Baird et al., 2013), and Coal River flow data from the Tasmanian Department of Primary Industries, Parks, Wildlife and the Environment. Daily model runs were scheduled subject to forcing data availability, with results displayed at http://www.marine.csiro.au/ and371/pitt/. The model runs at $50 \mathrm{x}$ real-time, on a compute server with 8 cores.

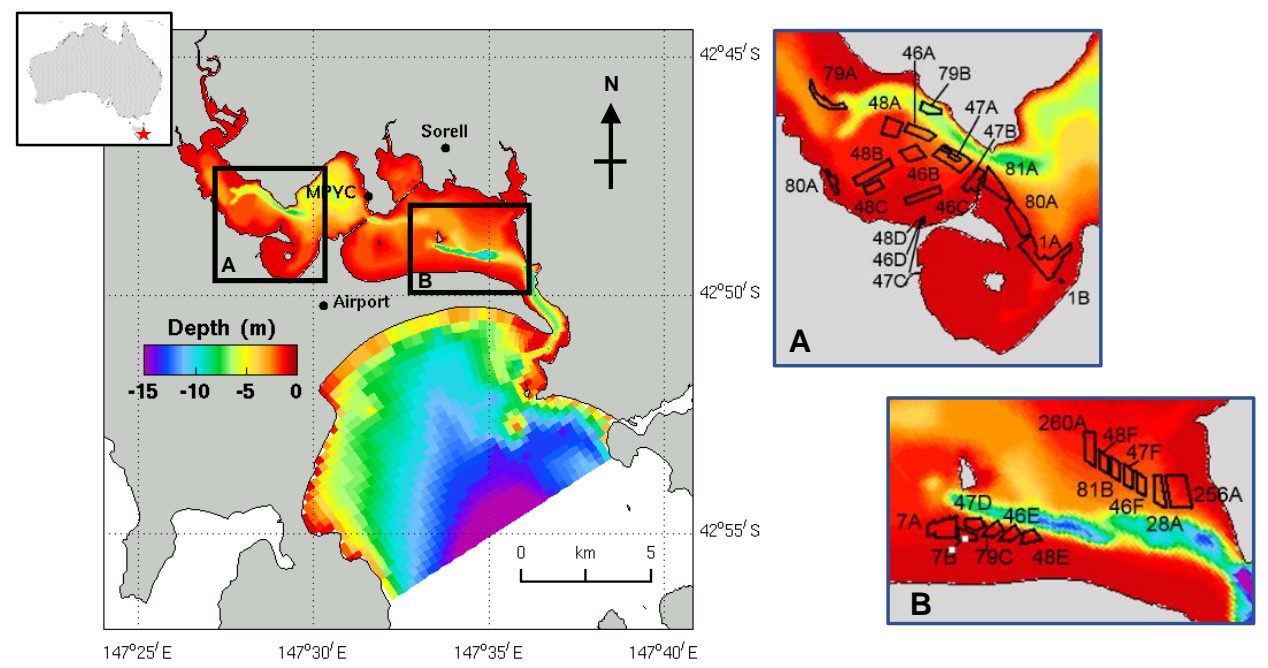

Figure 1. Pittwater model bathymetry (at grid resolution) and oyster leases (insets A \& B). 


\section{MODEL ASSESSMENT}

The model has been validated and calibrated against temperature, pressure and salinity sensor data (accessed from a local company called 'The Yield') in Barilla Bay and Belbins Saltpan. Observed pressure data captures both the tidal and low frequency components of sea level variation. The model reproduces the ongoing observed tidal and low frequency sea level variation very well which gives us confidence in the accuracy of the simulated water circulation, influx and outflow from the Lagoon system (Figure 2).

Simulation of salinity and temperature in the Lagoon presents a significant challenge as the water column is extremely shallow with many tidal flats, allowing for extreme localized heating, cooling and evaporation. The timing of and magnitude of observed fluctuations in temperature and salinity are well reproduced by the model (Figure 2) indicating that the main drivers of the thermal and salinity dynamics in the Lagoon are well captured in the model, however there was a small negative bias in salinity and a small positive bias in temperature in summer 2016 likely due to unresolved or sub grid scale mudflat heating.
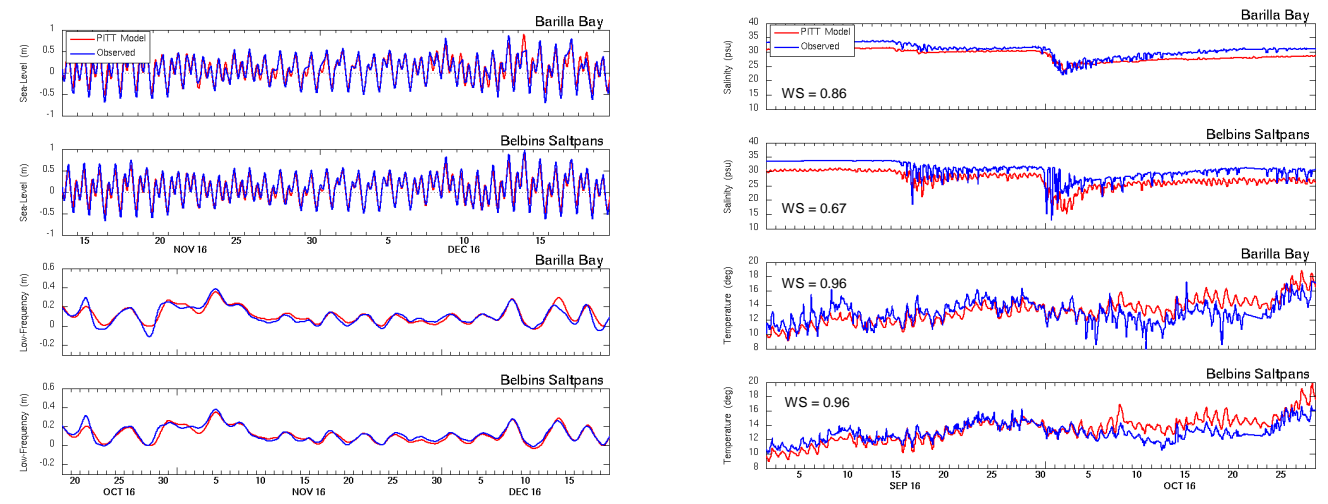

Figure 2. Comparison of model and observations for sea level (tide \& low-frequency variation) [left], temperature and salinity [right] with Wilmot Skill metric (Wilmot 1981; 1= perfect agreement).

The primary use of the hydrodynamic model in this study is to reproduce the circulation and flushing of the lagoon system for the investigation of potential spill dispersal scenarios. Given the very accurate model representation of low frequency and tidal variation in sea level height we are confident that the model is fit for this purpose.

\section{MODEL RESULTS}

Spatial plots of model results show a persistent gradient in salinity with elevated concentration in the inner Lagoon particularly in summer and autumn (Figure 3). This is due to the very low influx of fresh water from the Coal River into the Lagoon system. During occasional periods of significant river flow, typically in winter or spring, this gradient in salinity is reversed with a freshening of the inner Lagoon. Temperature in the Lagoon is modulated primarily by sea surface heating during the day and cooling at night. Exposed mudflats can generate localized heating (Figure 3), cooling and evaporation, which impacts the water column on subsequent tidal inundation.
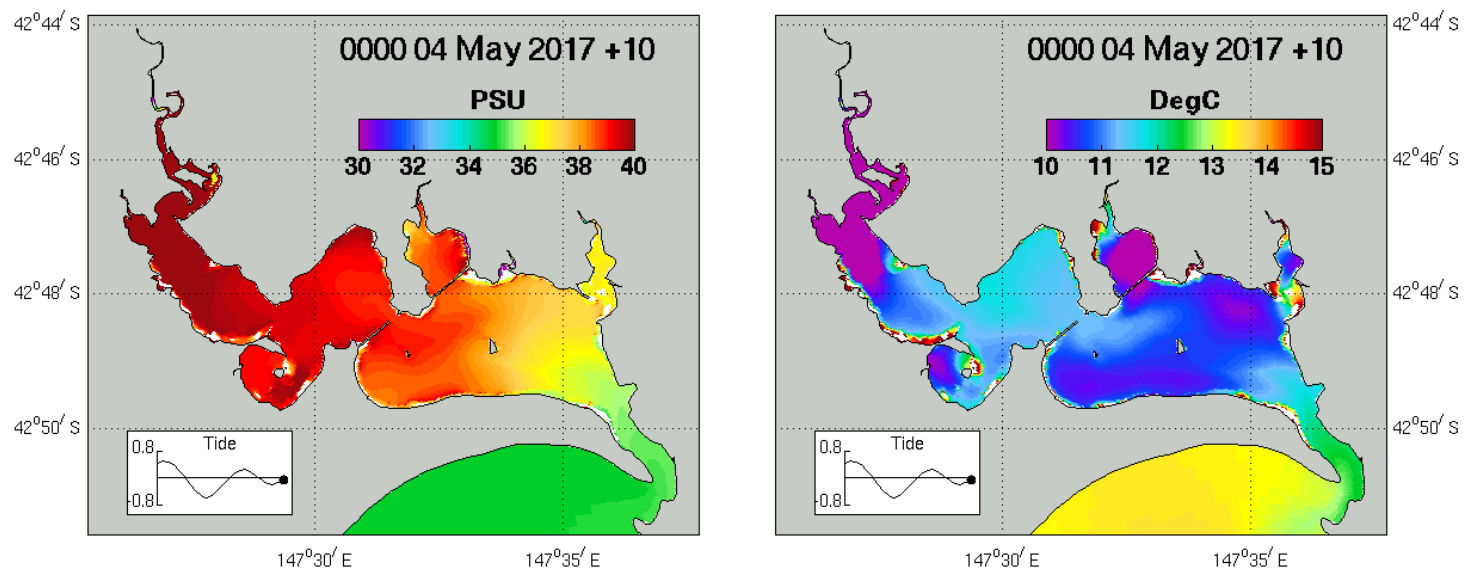

Figure 3. Example model forecast of salinity (left) and temperature (right). 
Circulation in the Lagoon is primarily modulated by bathymetry with the strongest currents aligned with the deep water channel which meanders diagonally through the outer Lagoon (Figure 4). There is an asymmetry in the tidal cycle which has a longer ebb and compressed flood phase. Surface currents are intensified downstream by wind stress with prevailing winds predominantly from the south west. There is little stratification in the lagoon due to the shallow bathymetry, tidal mixing and generally low Coal River flow.

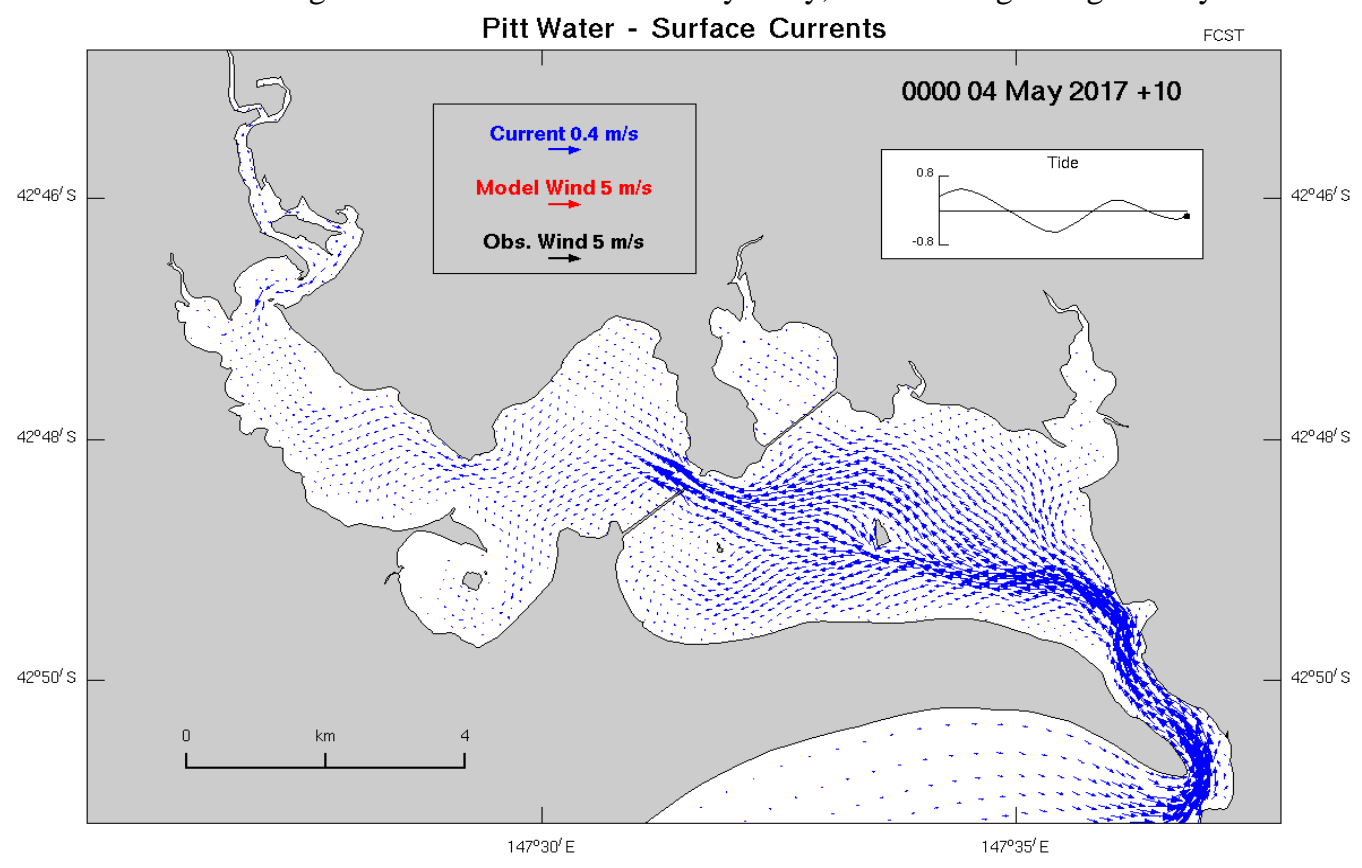

Figure 4. Example model forecast of surface currents

\section{SPILL SCENARIO SIMULATIONS}

The hydrodynamic model was deployed to assess the likely spatial and temporal dispersal of potential spill events from known local storm water drains and sewerage treatment plant (STP) infrastructure vulnerabilities.

The near real time simulation of potential effluent spills was achieved by the periodic release of passive tracer particles from specified locations. Movie loops of particle dispersal from each location are displayed on the web at http://www.marine.csiro.au/cem/pitt/anim_pitt_part.gif . Results are updated every few days to provide a synopsis of recent conditions and a short term forecast.

More detailed analysis of a number of specific spill scenario simulations was also achieved. A selection of spill scenarios were identified by TasWater (Table 1). Repeated hind-cast simulations were made for the duration of September 2016 with contrasting Coal river flow and wind direction [all wind from NE; all wind from NW]. Scenario Coal river flow was set at a constant level of low flow $=0 \mathrm{~m}^{3} \mathrm{~s}^{-1}$, median flow $=0.0605$ $\mathrm{m}^{3} \mathrm{~s}^{-1}$, or high flow $=30.0 \mathrm{~m}^{3} \mathrm{~s}^{-1}$ based on the analysis of flow from November 2015 to March 2017. Neap tides occurred on 3-8 September and Spring tides peaked between 23-26 September. For scenarios 2, 9 and 11 (Table 1) continuous discharge of a passive tracer was simulated from the specified location for the neap or spring tide time period. For scenarios 9 (Table 1) the discharge of passive tracer from Cambridge STP was limited to within 2 hours of high tide for both spring and neap tide time periods.

Table 1. Selection of spill scenarios defined by TasWater.

\begin{tabular}{|l|l|l|l|l|}
\hline Scenario No. & Discharge Location & Tide & Coal River Flow & Wind Dir. \\
\hline $\mathbf{2}$ & Sorell STP & Neap Tide & Average & NE \\
\hline $\mathbf{7}$ & $\begin{array}{l}\text { Cambridge STP } \\
\text { 2 hours +/- high tide only }\end{array}$ & Spring Tide & Average & NW \\
\hline $\mathbf{9}$ & Richmond STP & Spring Tide & High & NE \\
\hline $\mathbf{1 1}$ & Barilla Rivulet Stormwater & Spring Tide & Low & NE \\
\hline
\end{tabular}




\section{SPILL SCENARIO RESULTS}

Near real time model results show particles expanding from each of the source locations and forming plumes subject to local currents (Figure 5). The speed of plume dispersal varies from week to week as local currents vary due to fluctuations in Coal river flow, tide and ambient wind.
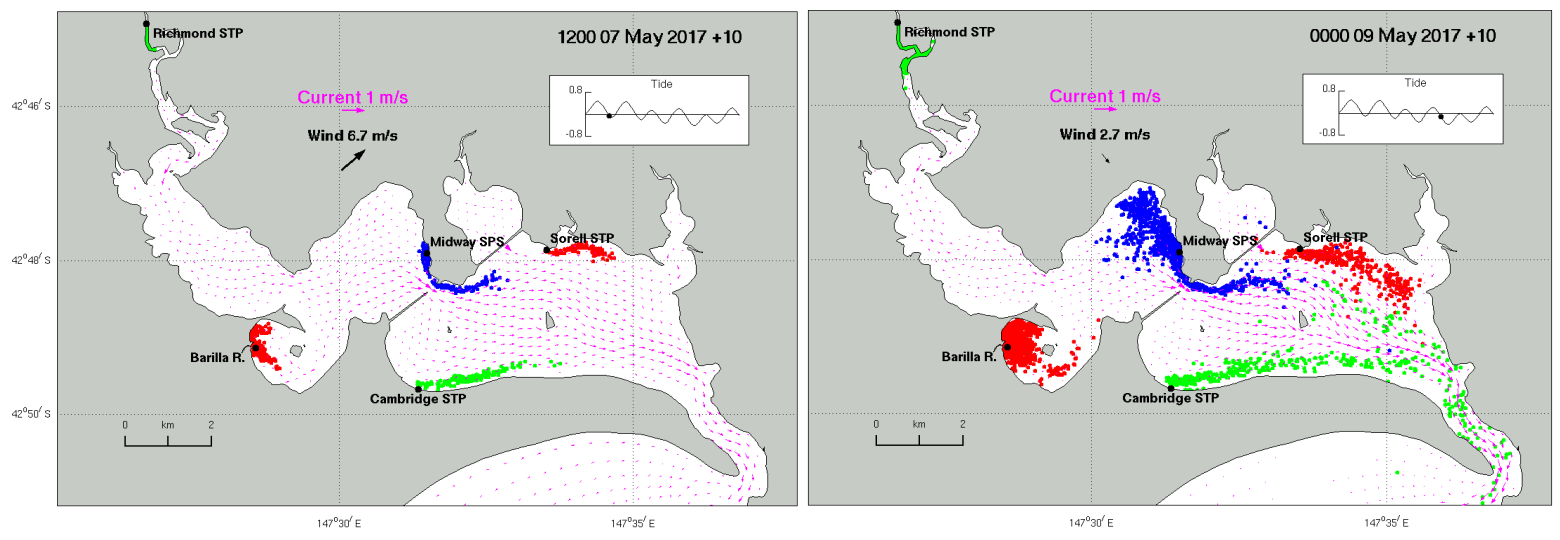

Figure 5. Particle dispersion 12 hours (left) \& 48 hours (right) after release during low river flow.

Results from the model scenarios (Table 1) were analysed to determine the time taken for $1 \%$ of the specified discharge to arrive at each oyster lease location (Figure $1 \& 6$ ). In general spills in the inner Lagoon rapidly arrived at oyster leases in the inner Lagoon, whilst spills in the outer Lagoon rapidly arrived at leases in the outer Lagoon. During spring tides spills were more rapidly distributed throughout the region and arrived at oyster leases faster than under comparable conditions at neap tides. Northwest winds slowed the dispersal of Sorell and Cambridge sources into the inner Lagoon by several days (compared to northeast winds).
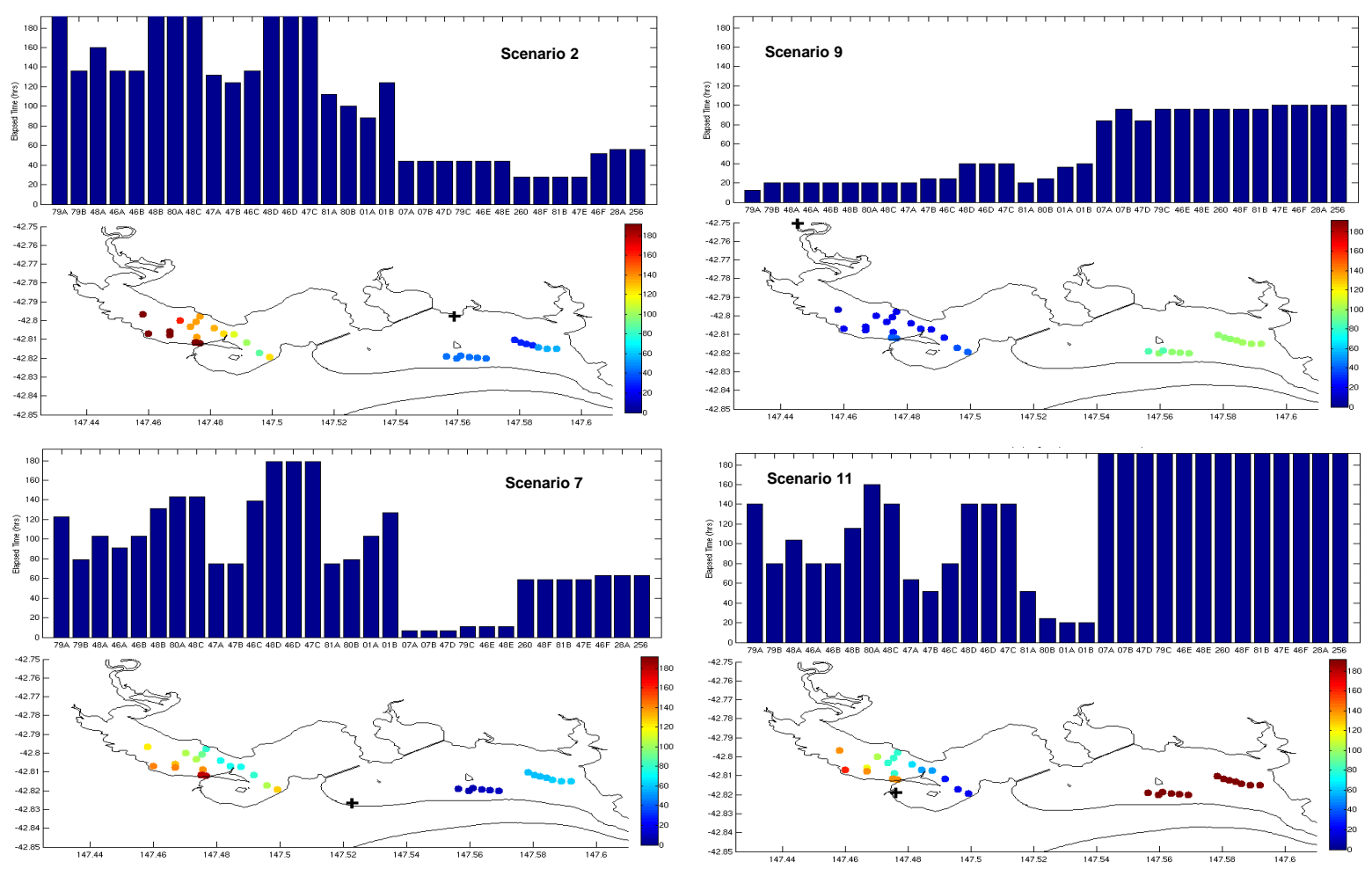

Figure 6. Elapsed time for effluent spill from + to arrive at each oyster lease for scenarios 2, 7, $9 \& 11$ [elapsed time range is 0 to 190 hours; bar graph leases are ordered from west to east]. 
The level of Coal river flow impacted the dispersal of spills from Richmond STP; under high flow oyster leases in the inner lagoon were quickly impacted, but under low flow the spill did not spread to any lease for over one week. Discharge at Barilla Rivulet during low Coal river flow remained in the inner Lagoon and was very slow to reach the outer Lagoon.

From this selection of scenarios it is clear that spills are most rapidly dispersed during periods of high Coal river flow and Spring tides. Northwest winds and neap tides slowed spills originating in the outer Lagoon from dispersing into the inner Lagoon.

\section{DISCUSSION}

This study has implemented a model, validated against in situ observations, that quantifies the spatial and temporal footprint of passive tracers released from infrastructure vulnerabilities in Pittwater Lagoon. Analysis of hind-cast scenario simulations shows variability in the arrival of tracer at individual oyster lease locations from less than 24 hours to more than 8 days depending on Coal river flow, tidal regime and wind direction. Near real time and forecast simulations provide live information of potential spill dispersal subject to evolving current conditions.

As the model is limited to hydrodynamic processes and conservative passive tracer dynamics results may be more conservative than the actual dispersal of an effluent spill. Microbial contamination can include bacteria, viruses and toxins dissolved in the water or attached to particles. These substances may be taken up by marine life, sink and be resuspended from the sediment or be transformed by biogeochemical processes. In addition pathogens encountering a favorable environment (e.g. suitable temperature range, ample nutrition) may multiply rapidly or conversely under challenging conditions (e.g. high UV light, lack of host particle) may naturally decline. Full resolution of these processes would require coupling the hydrodynamic model to a sediment and biogeochemical process model (Wild-Allen et al., 2016) with added resolution of microbial pathogens (Jovanovic et al., 2015; Preston et al., 2016).

Notwithstanding the uncertainty in the presence (or absence) of microbial contamination in the environment, there is the further step of ingestion of this material into the shellfish to be considered. Dabrowski et al., (2014) modelled the accumulation and depuration of E.coli in mussels in Bantry Bay southwest Ireland and used their model to classify shellfish water quality and provide a short term forecast of shellfish contamination. Their study could be usefully extended to other shellfish, such as oysters, and pathogens such as Norovirus and applied in Australian waters.

Our study shows that passive tracer releases can take more than 8 days to arrive at distant leases, which suggests that effluent spills are unlikely to compromise the whole Pittwater Lagoon system immediately. This offers the possibility of there being a 'window of opportunity' to continue farm operations at farms experiencing a delay in contamination. Such information is potentially of great value to the shellfish farming industry which in Pittwater Lagoon during peak season harvested up to $\$ 1 \mathrm{M}$ of product per week pre 2016 (personal communication with Justin Goc - Barilla Bay Oysters). Since 2016 Pittwater Lagoon has experienced a significant downsizing of production due to the arrival of Pacific Oyster Mortality Syndrome (Whittington et al., 2016); this makes the financial burden of any unnecessary closure even more critical to the viability of the besieged industry.

As microbial contamination of shellfish for human consumption can lead to severe illness (Butt et al., 2004; Lees 2000) we recommend further validation of the model predictions prior to uptake by the regulator. Deployment of an in situ sampling system (e.g. Breier et al., 2014) would allow confirmation of the predicted arrival (or departure) of microbial contamination at an oyster lease. Assuming the model demonstrates some predictive skill, it could then be usefully deployed by the regulator to refine decisions to open or close specific oyster leases within the whole Pittwater Lagoon system following an effluent spill. Our modelling approach could also be generalized to other shellfish farming areas and species. 
Wild-Allen et al., Modelling Pittwater Lagoon for risk assessment of an effluent spill

\section{ACKNOWLEDGEMENTS}

This work was jointly funded by CSIRO Oceans \& Atmosphere and TasWater. We gratefully acknowledge the support of our colleagues in the CSIRO Coastal Environmental Modelling Team, Simon Allen of Spatial Analytics for provision of bathymetry data, The Yield for access to sensor data, and Justin Goc of Barilla Bay Oysters for details of farm operations.

\section{REFERENCES}

Baird, M.E., Ralph, P.J., Rizwi, F., Wild-Allen, K. \& Steven, A.D.L. (2013). A dynamic model of the cellular carbon to chlorophyll ratio applied to a batch culture and a continental shelf ecosystem. Limnology \& Oceanography 58(4), 1215-1226.

Butt, A. A., Aldridge, K. E., Sanders, C. V. (2004). Infections related to the ingestion of seafood part I: viral and bacterial infections. The Lancet Infectious Diseases, 4(4), 201-212.

Dabrowski, T., Doré, W.J., Lyons, K., Nolan, G.D. (2014). Numerical modelling of blue mussel (Mytilus edulis) bacterial contamination. Journal of Sea Research 89: 52-63.

Fleming, L.E., Broad, K., Clement, A., Dewailly, D., Elmir, S., Knap, A., Pomponi, S.A., Smith, S., Solo, H., Gabriele, Walsh, P. (2006). Oceans and human health: Emerging public health risks in the marine environment. Marine Pollution Bulletin 53:545-560.

Herzfeld, M., Waring, J., Parslow, J., Margvelashvili, N., Sakov, P. and Andrewartha, J. (2010). SHOC Sparse Hydrodynamic Ocean Code V1632 Scientific Manual. CSIRO Marine Research Report, July 2010.

Jones, E. M., P. R. Oke, F. Rizwi, L. Murray. (2012). Assimilation of glider and mooring data into a coastal ocean model. Ocean Model. 47: 1-12, doi:10.1016/j.ocemod.2011.12.009

Jovanovic, D., Henry, R., Coleman, R., Deletic, A., McCarthy, D. (2015). Integrated conceptual modelling of faecal contamination in an urban estuary catchment. Water Science and Technology 72 (9):1472-1480, doi: 10.2166/wst.2015.363

Lees, D. (2000). Viruses and bivalve shellfish. International Journal of Food Microbiology, 59(1-2), 81- 116.

Muniain-Mujika, I., Calvo, M., Lucena, F., \& Girones, R. (2003). Comparative analysis of viral pathogens and potential indicators in shellfish. International Journal of Food Microbiology, 83(1), 75-85.

Oliveira, J., Cunha, A., Castilho, F., Romalde, J.L., Pereira, M.J. (2011). Microbial contamination and purification of bivalve shellfish: Crucial aspects in monitoring and future perspectives - A mini-review. Food Control 22:805-816.

Preston, D.L., Mischler, J.A., Townsend, A.R., Johnson, P.T.J. (2016). Disease Ecology Meets Ecosystem Science. Ecosystems 19: 737-748, doi: 10.1007/s10021-016-9965-2 .

Whittington, R., Hick, P., Evans, O., Rubio, A., Dhand, N., Paul-Pont, I. (2016). Pacific oyster mortality syndrome: a marine herpesvirus active in Australia. Microbiology Australia, 37(3):126-128, doi:10.1071/MA16043.

Wild-Allen, K., Rayner, M., Gillibrand, P., Revill, A., Schwanger, C. Rizwi, F., Clementson, L., Carlin, G. (2014). Southern Water Project Wastewater Management Estuarine Discharge Stage 2. CSIRO Marine and Atmospheric Research Final Report, November 2014.

Wilmot, C.J. (1981). On the validation of models. Phys. Geogr., 2, 184-194.

Woehler, E.J. (2013). Resident Shorebirds and Seabirds of the Pitt Water Orielton Lagoon Nature Reserve and Ramsar Site. BirdLife Tasmania Report to NRM South February 2013. www.nrmsouth.org.au/wp-content/uploads/2014/10/residentshorebirdsandse.pdf . 